\section{SPECIFICITY OF VISUAL SYSTEM IN SOCIAL POSTERS ON DOMESTIC VIOLENCE}

Liliana Vezhbovska, https://orcid.org/0000-0003-1886-1477

$\mathrm{PhD}$ in Arts, Associate Professor at the Graphic Design Department,

Kyiv National University of Culture and Arts,

Kyiv, Ukraine

lilianavezhbovska@gmail.com

Iryna Solan,

https://orcid.org/0000-0001-9101-6021

6 course Master's Degree student of the Design and Advertising Faculty,

Kyiv National University of Culture and Arts, Kyiv, Ukraine solanara97@gmail.com

\section{СПЕЦИФІКА ВІЗУАЛЬНОÏ СИСТЕМИ У СОЦІАЛЬНИХ ПЛАКАТАХ НА ТЕМУ ДОМАШНЬОГО НАСИЛЬСТВА}

\section{Ліліана Вежбовська,} https://orcid.org/0000-0003-1886-1477

кандидат мистецтвознавства,

доцент кафедри

графрічного дизайну,

Київський національний університет

культури і мистецтв,

Київ, Україна

lilianavezhbovska@gmail.com

\section{Ірина Солан,}

https://orcid.org/0000-0001-9101-6021

студентка 6 курсу

Факультету дизайну і реклами,

Київський національний університет

культури і мистецтв,

Київ, Україна

solanara97@gmail.com

\section{Abstract}

The aim of the study is to identify the specificity of graphic means and techniques used in social posters on domestic violence. Research methods. The general scientific methods of analysis, synthesis, comparison, iconological and sociological methods are applied in the work. Scientific novelty. Using the example of a social poster, the study reveals the specificity of visual system most appropriate in campaigns against domestic violence. The relevance of the topic is caused by the need to find out the reasons for the low effectiveness of social advertising in Ukraine on this theme, which is discovered, first of all, by the low public awareness of
Анотація

Метою дослідження $€$ виявлення специфіки застосування графічних засобів іприйомів, художньо-образних рішень у соціальних плакатах на тему сімейного насильства. Методи дослідження. У роботі застосовано загальнонаукові методи аналізу, синтезу, порівняння; іконологічний та соціологічний метод. Новизна дослідження. На прикладі дослідження соціального плаката виявлено специфіку візуальної системи, найбільш доцільної у кампаніях проти домашнього насильства. Актуальність теми викликана потребою з'ясувати причини низької ефективності в Україні соціальної ре- 
the social problem. Conclusions. The results of the study confirmed the specificity of the social posters' visual language on the topic of domestic violence, which consists in the application of such ideas and images that would appeal to the viewer through empathy, self-identification, and the effect of shock. It has been found that with the help of figurative, color, and compositional ratios, it's possible to qualitatively improve the effectiveness of domestic violence advertising campaigns.

\section{Keywords: Ключові слова:}

social poster, domestic violence, visual system, graphic means, graphic techniques. клами на дану тему, що виявлено, передусім, низькою поінформованістю громадськості про суспільну проблему. Висновки. Результати дослідження засвідчили специфіку візуальної системи соціальних плакатів на тему домашнього насильства, яка полягає у застосуванні таких ідей та образів, які б зверталися до глядача через емпатію, самоототожнення чи епатаж. Виявлено, що за допомогою образних, колірних та композиційних співвідношень можна якісно підвищити ефективність рекламних кампаній на тему домашнього насильства.

соціальний плакат, домашнє насильство, візуальна система, графічні засоби, графічні прийоми.

Домашнє насильство - актуальна проблема не лише в Україні, а й в усьому світі. Вона стосується людей різних економічних статусів і культур. Згідно зі статистикою, домашнє насильство стає причиною смерті більше, ніж півтора мільйона людей у світі щоденно. Окрім того, явище може нести складні психологічні, фізіологічні та економічні наслідки для його жертв, що невдовзі позначається на всій соціальній спільноті. Відомо, що насильство $є$ основною причиною смерті людей віком від 15 до 45 років ("Щороку в Україні", 2017).

В Україні щороку гинуть від домашнього насильства 600 представниць слабкої статі. Розрахунки, проведені $\mathbf{l}$ ститутом демографії і соціальних досліджень на замовлення Фонду народонаселення ООН, свідчать про те, що щорічно 1,1 млн українок стикаються з фізичною та сексуальною агресією в сім'ї. I більшість з них мовчать. Так, за даними Українського інституту соціальних досліджень, лише 27 \% жінок вважають образи проявом насильства, і тільки 32 \% подібним чином оцінюють приниження. Для 49 \% респонденток насильство - це побої, а 56 \% згодні вважати насильством лише зґвалтування ("Щороку в Україні", 2017).

Враховуючи, що відсоток жінок, котрі вважають насильство «нормальним явищем», набагато нижчий у більш розвинутих 
країнах, можна зробити висновок, що українське населення не достатньо поінформоване про проблему.

У світовій практиці ця тема давно має ефективні засоби інформування і захисту жертв домашнього насильства. Проте в Україні, незважаючи на ухвалення закону від 07.12.2017 № 2229-19 «Про запобігання та протидію домашньому насильству» (2017), все ще бракує як механізмів його впровадження, так і свідомих дій громадян, які б добивалися відповідальності насильника та захисту його жертв. Соціальні кампанії хоч і проводилися, проте, на нашу думку, їм бракувало всеохопності та ефективності. Причини такого явища можуть бути пов'язані значною мірою з низькими затратами ресурсів на створення відповідної реклами, непродуманістю цілісної кампанії, зокрема, іiї візуальної системи. Відтак, через відсутність виразних візуальних засобів цінна інформація губиться у стрімких інформаційних потоках чи витісняється іншою, більш якісно організованою продукцією.

Окрім того, у сфері дизайну не проводилось на цю тему наукових досліджень, які б мали за мету виправити ситуацію. В рамках цієї статті буде розглянуто тільки один аспект значної комплексної проблеми: особливості візуальної системи на прикладі соціального плаката - одного з найяскравіших рекламних продуктів.

Мета 2
дослідження

Метою дослідження є виявлення специфіки візуальної системи у соціальних плакатах на тему сімейного насильства; пошук ефективних рішень, образів, ідей, які здатні донести важливу інформацію до якомога більшої кількості людей. Під візуальною системою розуміємо прийоми і засоби графічного дизайну, а також - художньо-образні рішення, які найбільш доцільні у реалізації соціальних кампаній проти домашнього насильства.

Методологія та аналіз джерельної бази
У роботі застосовано загальнонаукові методи аналізу, синтезу, порівняння, іконологічний та соціологічний метод.

Базовими працями для нашої статті стали наукові дослідження особливостей візуальної мови графічного дизайну (Гладун, 2013); дослідження дизайну зовнішньої реклами в Україні кінця XX - початку XXI ст. (Авраменко, 2014); дослідження соціального плакату як засобу реклами (Бистрякова, Осадча, \& Гула, 2017). Джерельною базою є наукова література, соціологічні дослідження та опис соціальних кампаній на тему домашнього насильства. Проте основний обсяг дослідження даної статті - викладення результатів власного візуального аналізу сучасних плакатів, які застосовуються в кампаніях проти домашнього насильства. 


\section{Результати дослідження}

Сучасні дослідники розглядають мову графічного дизайну як «універсальний засіб репрезентації, організації і трансляції інформації, здатної забезпечити збереження й передачу соціального досвіду» (Гладун, 2013, с. 21). Продукцію графічного дизайну можна вважати базовою у сфері реклами взагалі і соціальної реклами зокрема. її ефективність залежатиме від того, чи вдалося донести до свідомості багатьох візуальне повідомлення, що, в свою чергу, залежить від вдалого поєднання багатьох елементів, спрямованих у русло заданої теми. У нашому дослідженні назвемо це явище «візуальною системою», під якою розуміємо всі елементи і способи їх творення, що беруть участь у формуванні візуального повідомлення: від графічних прийомів і засобів до художньо-образних рішень.

Одним із найбільш виразних видів соціальної реклами є плакат. Його важливою особливістю є зображення великого формату, яке найчастіше супроводжується коротким текстом. На думку дослідників, «візуально-графічна складова плаката виступає як соціальний комунікатор, який впливає на споживача через художній образ» (Бистрякова, 2017, с. 1166). У такий спосіб соціальні плакати сприяють формуванню настанов, ідей, етичних принципів, переконань і стереотипів. Проте, все ж головною їхньою функцією є можливість схиляння читача до дії.

Досліджувані в роботі плакати умовно можна розділити на дві групи: створені за допомогою фото та створені за допомогою зображень (ілюстрацій). Основна відмінність між ними виявляється у досягненні різних рівнів емоційного та інтелектуального навантаження. Так, за допомогою фотографій істотніше передається емоційний стан зображуваної людини. Також варто враховувати, що плакати, створені з використанням фото, є більш реалістичними, а тому, певною мірою, легшими для сприйняття глядачами, в той час як графічно створені плакати повинні бути виконаними більш метафорично й образно.

Одним з основних аспектів при створенні соціального плакату є вибір кольорової гами. Безумовно, кольори фото та ілюстрацій істотно відрізняються, графічні плакати більш активно застосовують колір на відміну від природних кольорів фотографічних плакатів. Колір у графічному плакаті дозволяє наділити зображення емоційним навантаженням, якого йому бракує порівняно з фотографічним.

Згідно з нашими спостереженнями, ілюстративні плакати зазвичай використовують три найпоширеніших серед соціальної реклами кольори: білий, чорний та червоний у різних його відтінках. Такі кольорові поєднання вже закріпилися у свідомості населення як кольори соціальної тематики. Проте, перевага в застосуванні цих кольорів призводить до однотипності ре- 
клами і її просто перестають помічати. Тому, на нашу думку, цей стереотип варто змінювати, вносячи нові кольори та відтінки.

Також слід відзначити особливі вимоги до сюжетного наповнення соціального плакату: часто він є складним для сприйняття, перевантаженим елементами. Плакати зазвичай розміщуються на вулицях міста, в метро, торгових центрах та в інших громадських місцях, тобто в місцях руху людей, саме тому на сприйняття того чи іншого зображення у перехожого $є$ лише кілька секунд. Якщо сюжет плакату буде надто деталізованим та перевантаженим, то глядач просто не встигне його зрозуміти. Сьогодні увагу глядача легше привернути мінімалістичним, але цікавим рекламним плакатом, аніж складним та багатозначним. Натомість, деталізовані роботи краще працюють у друкованій поліграфічній продукції, у соціальних мережах або на веб-банерах, тобто в місцях, де глядач має змогу розглядати зображення кілька хвилин.

Композиція рекламних плакатів також відіграє одну з ключових ролей, адже завдяки їй увага глядача спрямовується в ту чи іншу частину зображення і сприяє сприйняттю інформації. У результаті аналізу доходимо висновку, що для соціальних плакатів краще за все обирати композицію з центральним розміщенням головного елементу для кращого акцентування та простішого сприйняття. Проте, беручи до уваги відомий факт, що людське око спрямоване на сприйняття зорової інформації з правого верхнього кута в лівий нижній кут, можна припустити, що розміщення головного елемента композиції, - наприклад, агресора або, навпаки, жертви, - у правому верхньому куті, також буде ефективним композиційним прийомом при створенні соціального плакату.

Текст у соціальному плакаті може відігравати як головну, так і другорядну роль. Проте важливим аспектом текстового наповнення є чіткість та стислість головного посилу. Під час аналізу аналогів соціальних плакатів ми оцінювали, в першу чергу, зображення, - адже саме вони повинні привертати основну увагу, в той час, як текст несе зазвичай інформативну функцію. Винятками є соціальні плакати, створені виключно за допомогою текстових композицій.

У даній роботі проаналізовано плакати на тему домашнього насильства, більшу частку яких становлять зразки, відібрані в мережі Pinterest. Серед них було виділено кілька основних груп, першу з яких складають плакати, створені за допомогою фотографій, а другу - плакати, створені за допомогою зображень, тобто малюнків, ілюстрацій. В аналізі плакатів увага зверталася на кольорову гаму, текстову частину, композицію, а також повідомлення, яке несе зображення загалом. 
Деміург: ідеї, технології, перспективи дизайну 2019 Том 2 № 2 Demiurge: ideas, technologies, perspectives of design 2019 Vol. 2 No 2

У плакатах з використанням зображень найчастіше можна спостерігати застосування прийомів контраформи та масштабування. Часто вони застосовуються одночасно.

Контраформа - це художній прийом, що дозволяє з різних за змістом форм скласти нове зображення. Причому, читатися має, передусім, та форма, на яку звернено увагу. Ймовірно, цей прийом є найбільш поширеним через те, що інтиригує читача, спонукає замислитися, що ж саме означає зображення. Дуже часто прийом акцентує порожнє зображення, відсилаючи нас до відтворення «відсутньої структури», а відтак, до усвідомлення причин цього явища. Окрім того, саме прийом контраформи надає зображенню лаконічності та простоти.

Звернемось до плакатів із застосуванням контраформи, за основу яких взято образ рук (рис. 4.1). «Руки мають висловлювати наміри душі»: так вважав ще Леонардо да Вінчі і дуже часто саме за допомогою рук передавав внутрішнє сум'яття портретованого чи певну інтригу. Досить згадати його «Пані з горностаєм», у якій вбачають портрет Цицилії Галерані, фаворитки міланського герцога Людовіко Сфорца, яка на той час відходить у тінь. Саме зображення рук спричиняє стрімку метаморфозу образу. Фіксуючи погляд на руках панянки, легко зауважити, що ії пальці далеко не ніжно впинаються в шкіру горностая, що був гербовим символом Сфорца. Цей зауважений жест раптом змінює динаміку всього образу: у первинно схопленому миловидному обличчі тепер прочитується тривога через ледь помітну скошеність у кутику губ. Таким чином, руки виявляють приховане.

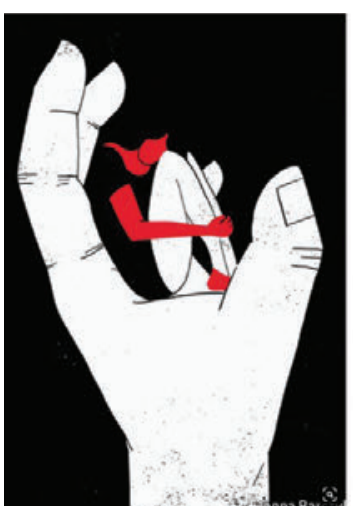

a

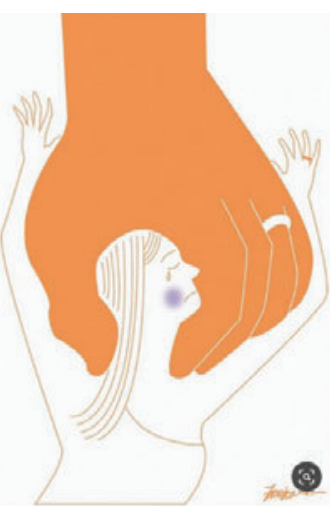

6

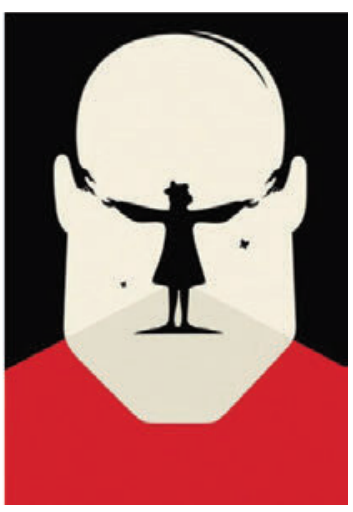

$B$

Рис. 4.1. Плакати із застосуванням прийомів контраформи, масштабування та образу рук.

Fig. 4.1. Posters with using counterform and scaling methods and image of hands. 
У плакатах подібну здатність цього образу використовують укупі із гіперболою і метафорою. Спостереження засвідчують, що переважно на таких плакатах зображені чоловічі руки. Найчастіше образ застосовується у плакатах на тему сексуального і фізичного насильства допомагає створити відчуття стиснення, удару або неприємного дотику. Такі відчуття виникають лише завдяки певному розміщенню і жесту рук.

Плакати із застосуванням контраформи часто мають у своій основі силуетне зображення людського обличчя. Такий образ також $є$ надзвичайно влучним, оскільки дає змогу глядачеві ототожнити себе із зображуваною особою.

Ще один прийом устворенні плакатів - масштабування (рис. 4.1). Це прийом, що створюється засобом збільшення або зменшення об'єктів, встановлення неприродних пропорційних співвідношень між ними. Це створює ефект гіперболізації іу рекламних кампаніях привертає увагу до самої проблеми. А також цей засіб допомагає образно розкрити ідею, унаочнити психологічні відчуття жертви та насильника. У такий спосіб глядач здобуває інформацію через емпатію (співпереживання), що має викликати усвідомлення потреби протидіяти насильству.

Знову ж таки, найчастіше цей прийом можна спостерігати у застосуванні щодо образу рук. Руку збільшено як уособлення тиранічної сили. Образ асоціюється з безпорадністю, відчаєм, страхом, залежністю (рис. 4.1, а, б). Також даний прийом застосовується для протиставлення розмірів силуетів: істотно зменшений силует людини на тлі іншого, загрозливого і могутнього, викликає відчуття безвиході перед аб'юзером. Часто застосовується образ могутньої руки, яка стискає крихітну постать. У цьому випадку поєднання масштабування і контраформи дає змогу образно донести ідею, виявити багаторівневість проблеми, змушує загострити свій зір та уяву. Подібні візуальні повідомлення мають за мету зробити глядача уважнішим до довколишньої дійсності, до людей, життя яких, можливо, залежить саме від нього.

Зауважимо, що розглянуті плакати складаються лише з зображень, які завдяки виразності образу можна вважати самодостатніми, такими, що не потребують додаткових пояснень. Ïх доцільно використовувати у друкованих чи електронних виданнях. Інших підходів вимагають плакати, які мають за мету донести якесь конкретне повідомлення і використовують текст.

Текст є надзвичайно важливим елементом плакату, адже саме завдяки йому глядач дізнається певну інформацію. Розміщення, розмір, колір тексту, його взаємодія з зображенням (якщо воно є), впливають на сприйняття та розуміння його глядачем. Тут діють загальні правила для плакатної продукції. По-перше, вся важлива інформація повинна читатися здалеку 
Деміург: ідеї, технології, перспективи дизайну 2019 Том 2 № 2 Demiurge: ideas, technologies, perspectives of design 2019 Vol. 2 No 2

і привертати увагу перехожих. По-друге, текст на плакаті має бути лаконічним або ж уся інформація повинна градіюватися за важливістю за допомогою розміру шрифту і кольору. Наприклад, головний посил з метою привернення уваги повинен бути великим і контрастним порівняно з тлом та іншим текстом.

Часто в плакатах текст використовують як частину зображення: у такому випадку він сприймається як об'єкт. У соціальних плакатах на тему насильства такий прийом часто застосовується для зображення саме психологічного насильства. Текст може утворювати певну фігуру або образ, наприклад, кулака або ножа, який наносить удар, також відомі зображення тексту у вигляді мотузки, обмотаної навколо шиї жертви. Такими образами автори зображень прагнуть показати, яку силу можуть нести навіть слова, підтверджуючи відомі приказки: «слово - не стріла, а глибше ранить»; «шабля ранить голову, а слово - душу».

Саме такий прийом вдало використано в серії плакатів, створених за допомогою фото (рис. 4.2). Ідеєю серії є зображення синців на тілі у вигляді образливих слів. Плакати висвітлюють проблему домашнього насильства стосовно дітей та дорослих - як психологічного, так і фізичного. Комбіноване зображення передає глядачу причинно-наслідкові зв'язки між результатом (тим, що зображено на плакаті) та його передумовами, а можливо, і наслідками.

Поширеним є й інший спосіб вписування тексту в зображення: його розміщення в самих фігурах або довкола них (рис. 4.3, зліва). Наприклад, тексту «Use your voice» (що в перекладі означає «використовуй свій голос») розміщений у відкритому роті силуета жінки (рис. 4.3, справа). Зображення спонукає не мовчати, сповістити про свою проблему, оскільки в іншому випадку про неї ніхто не дізнається.
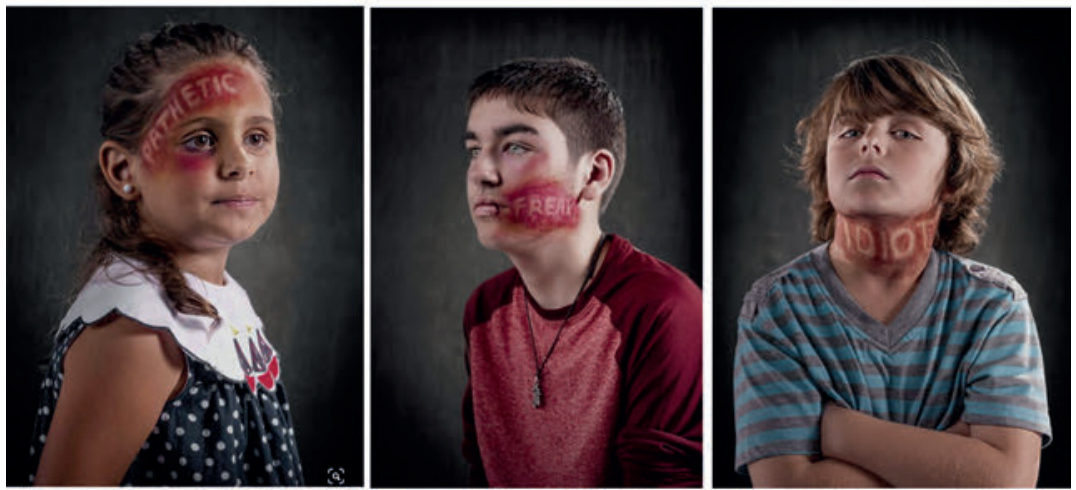

Рис. 4.2. Постери із візуалізацією причинно-наслідкових зв'язків за допомогою фотографії і тексту.

Fig. 4.2. Posters with visualization of causes and effects through photos and text. 

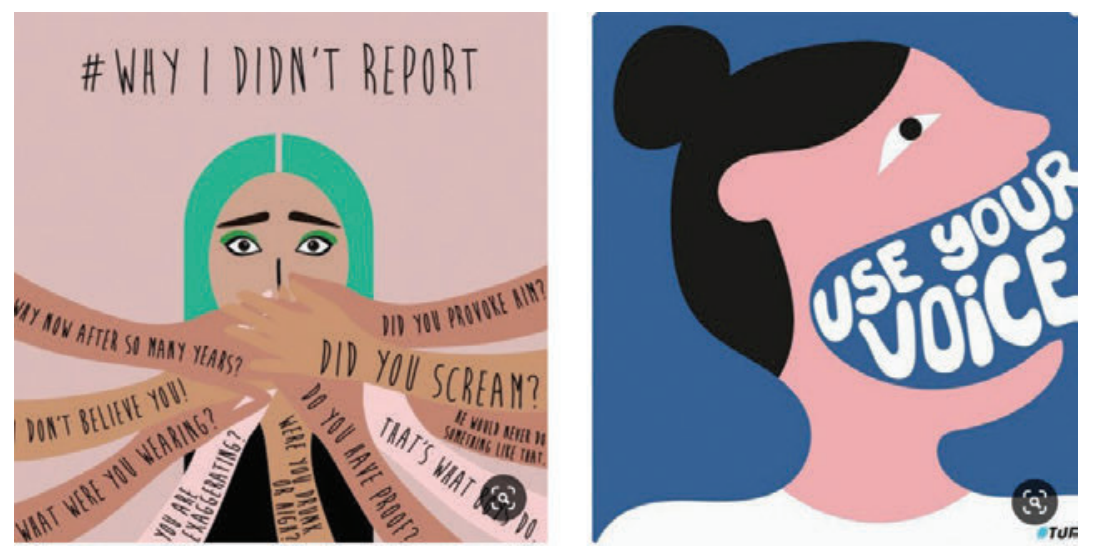

Рис. 4.3. Плакати із застосуванням тексту, що забезпечує діалог з глядачем та закликає до певної поведінки.

Fig. 4.3. Posters with using text that provides dialogue with the viewer and encourages appropriate behavior.

Ще один вид проаналізованих плакатів - плакати, створені на основі комбінування растрової графіки з фотографією, колажування. Соціологічні опитування засвідчують, що саме такі плакати мають значний вплив на глядача, оскільки емоції живих людей, зображені на світлинах, та додаткові, оброблені дизайнером, швидше викликають емпатію, ніж малюнок. На плакатах переважно зображено обличчя жінок, дітей, на яких чітко видно синці та побої, або частини тіла з виразними слідами порізів. Такий образ є найпоширенішим у соціальній рекламі проти домашнього насильства, проте й досі найбільш ефективним. Зокрема, згаданим технічним прийомом комбінування та колажуванням забезпечено оригінальний дизайн та ефектність у плакатах, які відтворюють образ «насильства як подарунка». У першому випадку це шрам на тілі жінки, поряд з яким - надпис: «Happy valentine's. Love John». У другому зображено букет, який замість квітів складається з чоловічих кулаків (рис. 4.4).

Тема домашнього насильства є настільки складною, що людина воліє іiї не помічати. Тому дизайнери, працюючи з цією темою, часто вдаються до застосування епатажних образів і крайніх метафор, здатних викликати у людини шок (рис. 4.5). Основною перевагою таких плакатів є привернення уваги глядача через максимальне оголення проблеми. Такі роботи викликають шквал обурення і безліч запитань, часто - крайні відчуття огиди, неприйняття, страху. А через неочікуваність надовго залишаються у свідомості.

Так, в одному з плакатів зображено м'ясну тушу, одягнену в жіночий одяг та підвішену на металеву конструкцію. Тут 
Деміург: ідеї, технології, перспективи дизайну 2019 Том 2 № 2 Demiurge: ideas, technologies, perspectives of design 2019 Vol. 2 No 2

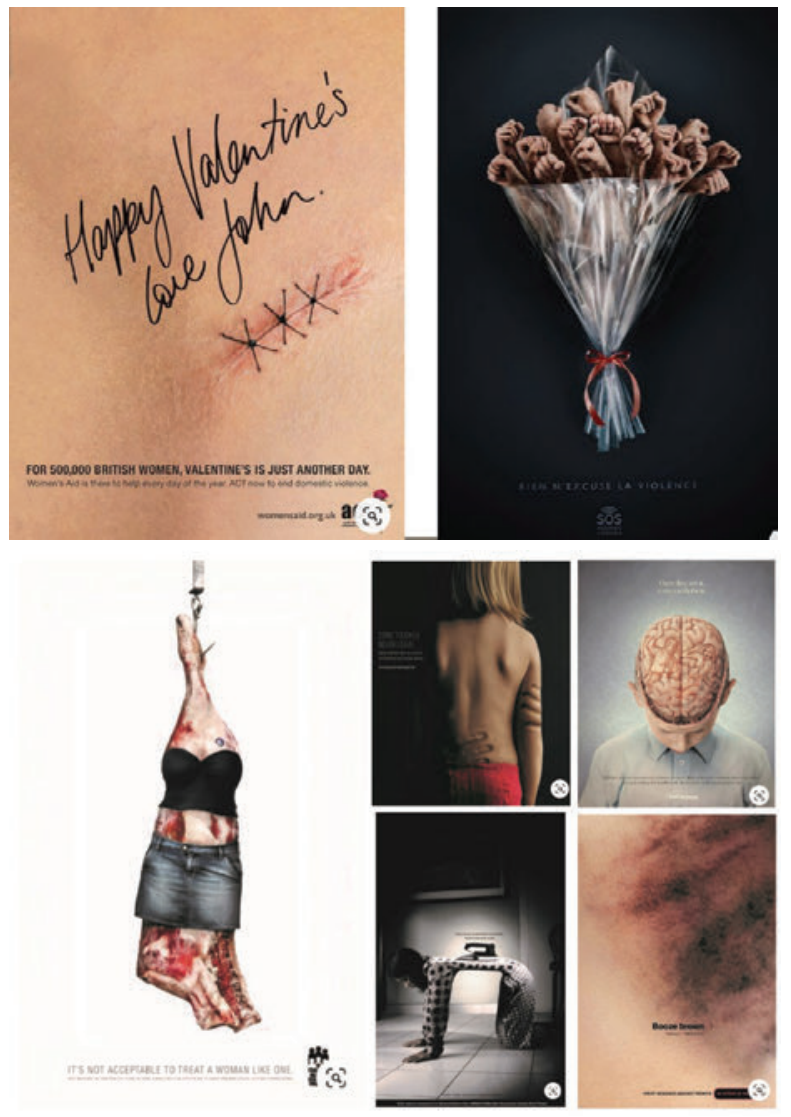

Рис. 4.4. Плакати із застосуванням образу подарунку та подвійним сенсом.

Fig. 4.4. Posters with using image of gifts and double meaning.

Рис. 4.5. Плакати із застосуванням епатажу і метафори.

Fig. 4.5. Posters with using shocking and metaphor.

застосована образна метафора: таким у даному разі є жіноче тіло для свого чоловіка (рис. 4.5, зліва). Наступний плакат спрямований проти домашнього і сексуального насильства над дітьми: у дитини, зображеної зі спини, на тілі чітко видно не просто сліди від сильних рук, а деформацію тіла їхніми відбитками (рис. 4.5, середній угорі).

Епатажно-метафоричний зміст, але з натяком на цілком реалістичні тортури - у фотографічному зображенні жінки як прасувальної дошки з праскою на її спині (рис. 4.5, нижній в середині). Тут також застосовано прийом деформації зображення у доведенні метафоричного зв'язку.

Наступний плакат вражає своєю «антиміметичністю»: упрагненні ідентифікувати зображення глядач несподівано опиняється сам на сам з «оголеною» проблемою. Розмите зображення виявляється фотографічним збільшенням фрагменту тіла з побоями. У такий спосіб плакат не залишає моральних шансів пройти повз його «крик» (рис. 4.5, нижній справа). 
Не менш вражаючим є плакат, що зображує вплив на дітей сцен домашнього насильства. Дитина зображена у позі страху і відчаю, з нахиленою головою. Автор сміливо викриває перед глядачем, що діється у дитячій свідомості під час сцени домашнього насильства у на її очах: у завитках головного мозку проявляються силуети - чоловіка, який б’є жінку. Ідеєю автора роботи було показати вплив домашнього насильства на психіку дитини, яка росте в токсичній атмосфері (рис. 4.5, верхній справа).

\section{Наукова \\ новизна та \\ практична \\ значимість дослідження

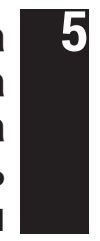

На прикладі дослідження соціального плаката виявлено специфіку застосування графічних засобів і прийомів, художньо-образних рішень , найбільш доцільних у кампаніях проти домашнього насильства. Актуальність теми викликана потребою з'ясувати причини низької ефективності в Україні соціальної реклами на дану тему, що виявлено, передусім, низькою поінформованістю громадськості про суспільну проблему. Результати дослідження мають практичне значення не лише для створення плакатів, але й іншої рекламної продукції чи для формування цілісного стилю й образу соціальних проектів на тему домашнього насильства: від логотипу, банера, білборда до інформаційної кампанії у соціальних мережах.

Висновки 6 Отже, результати дослідження засвідчили, що тема домашнього насильства у соціальній рекламі, зокрема, плакаті, потребує візуальної системи, яка встановлює комунікацію з глядачем через емпатію, самоототожнення чи через шокування свідомості. Аналіз відповідних плакатів доводить, що соціальна реклама на згадану тему відрізняється від інших підвищеним градусом напруги, висловленим на межі крику, поклику про допомогу, закликом не мовчати. В таких умовах зростає значення образних, колірних та композиційних співвідношень. Не менш важливим є текст повідомлення чи застосування текстових композицій у плакаті. Окрім того, серед плакатів із застосуванням ілюстрації найпоширенішими прийомами визначено застосування контраформи, масштабування. Та найбільш сугестивними залишаються плакати із застосуванням фотографії, оскільки вони здатні більш емоційно впливати на глядача. Таким чином, за допомогою згаданих графічних засобів можна якісно підвищити ефективність рекламних кампаній на тему домашнього насильства. 


\section{Список бібліографічних посилань}

Авраменко, Д.К. (2014). Дизайн зовнішньоїреклами в Україні кінець XX - початок XXI століття. Вісник Харківської державної академії дизайну імистецтв. Мистецтвознавство. Архітектура, 3, 4-7.

Бистрякова, В., Осадча, А., \& Гула, Є. (2017). Плакат як засіб соціальної реклами. Народознавчі зошити, 5(137), 1162-1167.

Гладун, О. (2013). Візуальна мова графічного дизайну як вторинна моделююча система. Вісник Харківської державної академії дизайну імистецтв. Мистецтвознавство. Архітектура, 2, 20-22.

Про запобігання та протидію домашньому насильству. (2017). № 2229-19, від 07.12.2017.

Щороку в Україні від домашнього насильства гинуть 600 жінок (інфографіка). (2017). УНІАН. Взято 3 https://www.unian.ua/society/2233774-schoroku-v-ukrajini-vid-domashnogonasilstva-ginut-600-jinok-infografika.html.

\section{References}

Avramenko, D.K. (2014). Dyzain zovnishnoi reklamy v Ukraini kinets XX - pochatok XXI stolittia [Outdoor advertising in Ukraine end of XX - beginning of XXI century]. Bulletin of Kharkiv state academy of design and arts. Art Studies. Architecture, 3, 4-7 [in Ukrainian].

Bystriakova, V., Osadcha, A., \& Hula, Ye. (2017). Plakat yak zasib sotsialnoi reklamy [Placet as a social advertising]. The Ethnology Notebooks, 5(137), 1162-1167 [in Ukrainian].

Hladun, O. (2013). Vizualna mova hrafichnoho dyzainu yak vtorynna modeliuiucha systema. [The visual language of graphic design as a secondary modeling system]. Bulletin of Kharkiv state academy of design and arts. Art Studies. Architecture, 2, 20-22 [in Ukrainian].

Pro zapobihannia ta protydiiu domashnomu nasylstvu [On the prevention and counteraction to domestic violence]. (2017). № 2229-19, from 07.12.2017 [in Ukrainian].

Shchoroku v Ukraini vid domashnoho nasylstva hynut 600 zhinok (infohrafika) [600 Ukrainian women die from domestic violence annually (infographic). (2017). UNIAN. Retrieved from https://www.unian.ua/society/2233774-schoroku-v-ukrajini-vid-domashnogo-nasilstvaginut-600-jinok-infografika.html [in Ukrainian]. 